\title{
Squash ball to eye ball: the likelihood of squash players incurring an eye injury
}

\author{
G V BARRELL，P J COOPER，A R ELKINGTON，J M MACFADYEN，R G POWELL，P TORMEY
}

\begin{abstract}
The records of the 118 patients treated at Southampton Eye Hospital during 1978-9 for injuries incurred while playing squash, badminton, tennis, table tennis, cricket, and football show that for squash the main cause of eye injury was the player being hit by the ball. Severe eye injuries - those requiring treatment as an inpatientwere rare but much more frequent than such injuries in other sports. Less serious injuries-those requiring treatment as an outpatient-were also rare, with a frequency comparable with that of similar injuries in football and badminton. Squash players are most unlikely to incur an eye injury, but should this occur it has far-reaching consequences both in the short and the long term. Each individual player must weigh these chances and consequences against the possible inconvenience of using some form of eye protection.
\end{abstract}

Department of Physical Education, University of Southampton, Southampton SO9 $5 \mathrm{NH}$

G V BARRELL, MA, MED, assistant

J M MACFADYEN, BA, director

Department of Social Statistics, University of Southampton, Southampton SO9 5NH

P J COOPER, BSocsc, MSc, lecturer

Department of Surgery, University of Southampton, Southampton SO9 5NH

A R ELKINGTON, FRCS, Do, senior lecturer in ophthalmology

R G POWELL, FRCs, lecturer in ophthalmology

Southampton Eye Hospital, Southampton SO9 4XW

P TORMEY, FRCSI, Do, senior registrar

\section{Introduction}

Squash rackets has become an increasingly popular game in Britain during the past few years. It was estimated in $1977^{1}$ that $1.9 \%$ of adults (those aged 16 and over) played, so that in England and Wales alone probably at least three-quarters of a million play.

The possibility of a player incurring a severe eye injury and suffering permanent visual impairment has been emphasised. ${ }^{2-4}$ The need to protect players' eyes is recognised both by those working in hospital ${ }^{56}$ and by the British Safety Council.? Nevertheless, those responsible for running the sports governing body, the Squash Rackets Association, do not seem convinced that protection of the eyes is necessary. One of their officials has been quoted as saying that he had "no evidence that eye injuries were on the increase," and also that he did not think that there was "any need for eye protection." 8

In the hope of contributing to this debate we set out to determine the likelihood of a squash player suffering an injury to an eye on court. In addition we compared the risk of incurring such injury from playing squash with that from other sports. To these ends we analysed the records of those seen during a two-year period at the Southampton Eye Hospital with eye injuries incurred while playing squash and various other ball games.

\section{Method}

The case notes of those adult patients who attended Southampton Eye Hospital during 1978 and 1979 with an injured eye as a result of playing squash, badminton, tennis, table tennis, cricket, or football were identified by referring to the inpatient ledger and all the casualty cards for these two years and abstracting details of the injury. Any comments on ocular abnormalities entered in the outpatient records during the period of follow-up were noted. The last available visual acuity was recorded. 


\section{Results}

Table I gives the results of the analysis of the records of patients suffering injuries to their eyes while playing various sports. The less serious injuries led to patients being treated as outpatients but all whose eyes were more seriously injured were admitted. Over the two years 58 adult patients were seen with eye injuries incurred while playing squash compared with badminton (23), football (22), tennis (9), cricket (5), and table tennis (1).

Table I also shows that the major causes of injury in the "bat and ball" sports requiring inpatient treatment were the squash ball (19/33) followed by the squash racket $(4 / 33)$ and the football $(3 / 33)$. For 85 outpatients the major causes of injury were the squash ball (22) and the football (19) followed by the shuttlecock (16) and the squash racket (13). These patterns are similar to those reported by Canavan et al. ${ }^{9}$

TABLE I-Analysis by sport and by cause of injury of 118 adult inpatients and outpatients seen during 1978 and 1979

\begin{tabular}{|c|c|c|c|c|c|c|c|}
\hline \multirow[b]{2}{*}{$\begin{array}{c}\text { Cause of } \\
\text { injury }\end{array}$} & \multicolumn{3}{|c|}{ Inpatients } & \multicolumn{3}{|c|}{ Outpatients } & \multirow{2}{*}{$\begin{array}{c}\text { All } \\
\text { patients } \\
\text { all } \\
\text { causes }\end{array}$} \\
\hline & $\begin{array}{c}\text { Ball or } \\
\text { shuttlecock }\end{array}$ & $\begin{array}{l}\text { Bat or } \\
\text { racket }\end{array}$ & $\begin{array}{c}\text { All } \\
\text { causes }\end{array}$ & $\begin{array}{c}\text { Ball or } \\
\text { shuttlecock }\end{array}$ & $\begin{array}{l}\text { Bat or } \\
\text { racket }\end{array}$ & $\begin{array}{c}\text { All } \\
\text { causes }\end{array}$ & \\
\hline $\begin{array}{l}\text { Squash } \\
\text { Badminton } \\
\text { Tennis } \\
\text { Table tennis } \\
\text { Cricket } \\
\text { Football }\end{array}$ & $\begin{array}{r}19 \\
2 \\
2 \\
0 \\
2 \\
3\end{array}$ & $\begin{array}{l}4 \\
1 \\
0 \\
0 \\
0 \\
-\end{array}$ & $\begin{array}{r}23 \\
3 \\
2 \\
0 \\
2 \\
3\end{array}$ & $\begin{array}{r}22 \\
16 \\
6 \\
1 \\
3 \\
19\end{array}$ & $\begin{array}{r}13 \\
4 \\
1 \\
0 \\
0 \\
-\end{array}$ & $\begin{array}{r}35 \\
20 \\
7 \\
1 \\
3 \\
19\end{array}$ & $\begin{array}{r}58 \\
23 \\
9 \\
1 \\
5 \\
22\end{array}$ \\
\hline All sports & 28 & 5 & 33 & 67 & 18 & 85 & 118 \\
\hline
\end{tabular}

with a sample size of just over 5000, of whom about 300 live in the Southern Region as defined by the Sports Council. This region includes Hampshire, the Isle of Wight, Berkshire, Buckinghamshire, and Oxfordshire. The available data ${ }^{1}$ allow us to estimate the percentage of the adult population in this region who play the six sports. The participation rate (days a week) for those playing each of these sports in England and Wales may also be estimated. In estimating the total number of days played (population $\times$ percentage playing the sport $\times$ participation rate) in the two-year period 1978-9 (in the Southern Region) we have used the percentage playing the sport for this region. We have assumed, however, that the participation rate for the Southern Region is the same as that for England and Wales.

Given that the rates estimated for the Southern Region are applicable to the Solent conurbation and that one session is played for each day of participation, then table II gives the numbers of sessions of play that we estimate have resulted in the injuries set out in table I.

The rates of injury in table II interpret table I in the light of the different exposure to risk, which has given rise to the recorded injuries. In inpatients the squash ball has by far the highest rate for eye injuries-1.7 injuries per 100000 sessions played. The highest outpatient injury rate is from the shuttlecock in badminton, 2.5 per 100000 sessions played, followed by the squash ball 2.0 and the football 1.7 . In our experience, therefore, squash is the sport most likely to cause a severe eye injury.

The estimate for the rate of injuries from the squash ball

TABLE II-Southampton Eye Hospital: injury rates by patient status, by cause of injury, and by sport, and the estimated number of playing sessions generating the observed injuries

\begin{tabular}{|c|c|c|c|c|c|c|c|c|}
\hline Sport & $\begin{array}{l}\text { Estimated number of } \\
\text { playing sessions generating } \\
\text { the observed injuries } \\
\text { (thousands) }\end{array}$ & $\begin{array}{c}\text { Ball or } \\
\text { shuttlecock }\end{array}$ & $\begin{array}{l}\text { Bat or } \\
\text { racket }\end{array}$ & $\begin{array}{c}\text { All } \\
\text { causes }\end{array}$ & $\begin{array}{c}\text { Ball or } \\
\text { shuttlecock }\end{array}$ & $\begin{array}{l}\text { Bat or } \\
\text { racket }\end{array}$ & $\begin{array}{c}\text { All } \\
\text { causes }\end{array}$ & $\begin{array}{l}\text { All patients } \\
\text { all causes }\end{array}$ \\
\hline $\begin{array}{l}\text { Squash } \\
\text { Badminton } \\
\text { Tennis } \\
\text { Table tennis } \\
\text { Cricket } \\
\text { Football }\end{array}$ & $\begin{array}{r}1123 \\
645 \\
692 \\
1163 \\
350 \\
1111\end{array}$ & $\begin{array}{l}1 \cdot 7 \\
0 \cdot 3 \\
0 \cdot 3 \\
0 \\
0 \cdot 6 \\
0 \cdot 3\end{array}$ & $\begin{array}{l}0 \cdot 3 \\
0 \cdot 2 \\
0 \\
0 \\
0 \\
-\end{array}$ & $\begin{array}{l}2 \cdot 0 \\
0 \cdot 5 \\
0 \cdot 3 \\
0 \\
0 \cdot 6 \\
0 \cdot 3\end{array}$ & $\begin{array}{l}2 \cdot 0 \\
2.5 \\
0.9 \\
0 \cdot 1 \\
0.9 \\
1.7\end{array}$ & $\begin{array}{l}1 \cdot 2 \\
0 \cdot 6 \\
0 \cdot 1 \\
0 \\
0 \\
\end{array}$ & $\begin{array}{l}3 \cdot 2 \\
3 \cdot 1 \\
1 \cdot 0 \\
0 \cdot 1 \\
0.9 \\
1 \cdot 7\end{array}$ & $\begin{array}{l}5 \cdot 2 \\
3 \cdot 6 \\
1 \cdot 3 \\
0 \cdot 1 \\
1 \cdot 5 \\
2 \cdot 0\end{array}$ \\
\hline All sports & 5084 & 0.5 & 0.1 & 0.6 & 1.3 & 0.4 & $1 \cdot 7$ & $2 \cdot 3$ \\
\hline
\end{tabular}

\section{VISUAL ACUITY AND OCULAR DAMAGE}

The duration of follow-up of the 23 patients admitted to hospital after being injured while playing squash varied from three to 18 months. Six patients were noted to have angle recession, which may predispose them to glaucoma later. In none of the six injured eyes was the intraocular pressure higher than in the fellow eye during the period of follow-up. One additional patient developed a retinal tear that was sealed by cryotherapy. The final visual acuity as recorded in the outpatient notes was $6 / 6$ or better in all but one of the 23 eyes. The exceptional eye was amblyopic (6/18). The injury was not thought to have led to further impairment of vision in this case.

The 35 outpatients had either a corneal abrasion or a microscopic hyphaema. The follow-up in all cases was for only a few days. In no case was the visual acuity recorded as being reduced.

\section{Discussion}

The incidence of injuries must be viewed against the background of the levels of participation in the various sports in the hospital catchment area. The catchment area of Southampton Eye Hospital extends over the major part of the Solent conurbation, an area containing about 315000 people aged 16 and over. $^{10}$

In 1977 the General Household Survey ${ }^{11}$ included questions about leisure time activities. The survey is carried out quarterly that require some form of treatment in hospital is 3.7 injuries per 100000 sessions played.

\section{LIKELIHOOD OF EYE INJURY}

Squash as a sport and the squash ball in particular are the major causes of the more serious eye injuries in the "bat and ball" games and in addition rank high among the causes of the less serious eye injuries requiring only treatment as an outpatient. The likelihood of a less serious injury from the squash ball is no greater than that from the ball or shuttlecock in football or badminton. Nevertheless, the likelihood of a more serious injury from the squash ball is much greater than that from the ball in all the other sports studied. The squash ball is particularly dangerous because it fits well into the anterior part of the orbit and because it travels fast ${ }^{12}$ (up to $54 \mathrm{~m} / \mathrm{s}$-that is, 120 $\mathrm{mph}$ ).

Table I shows that the ball caused 19 of the 23 eye injuries incurred while playing squash that required treatment as an inpatient. North ${ }^{3}$ also found that the ball caused 22 of the 28 more serious eye injuries incurred while playing squash. The only other estimate of the likelihood of a squash player incurring an injury to the eye that we have found is that of Clemett and Fairhurst, ${ }^{13}$ whose study was confined to competitive games. They sampled 10658 games (about 21300 playing sessions) 
and recorded two eye injuries. Both patients had a hyphaema and one also had a choroidal rupture. Given that these injuries were caused by the ball, the rate of 9.4 eye injuries per 100000 competitive playing sessions is no different from our observed rate at the $5 \%$ level of significance.

We thank M J Absolon, I H Chisholm, J I McGill, and C B Walker for allowing us to study the notes of patients under their care. We are indebted to Professor W E Waters for his helpful criticism, and we are grateful to the Southampton University Department of Teaching Media for the illustration.

\section{References}

1 Veal AJ. Sport and recreation in England and Wales: an analysis of adult participation patterns in 1977. Birmingham: Leisure and Tourism Unit, Centre for Urban and Regional Studies, University of Birmingham, 1979. (Research memorandum 74.)

2 Ingram DV, Lewkonia I. Ocular hazards of playing squash rackets. Br 7 Ophthalmol $1973 ; 57: 434-8$.
${ }^{3}$ North IM. Ocular hazards of squash. Med $\mathcal{f}$ Aust 1973;1 :165-6.

${ }^{4}$ Easterbrook M. Eye injuries in squash: a preventable disease. Can Med Assoc f 1978;118:303-5.

${ }^{5}$ Moore MC, Wortheley DA. Ocular injury in squash players. Australian fournal of Ophthalmology 1977;5:46-7.

${ }^{6}$ Easterbrook M. Eye injuries in racquet sports: a continuing problem Can Med Assoc F 1980;123:268-9.

${ }^{7}$ British Safety Council. News from the press office. London: British Safety Council, April 1980.

${ }^{8}$ Fishlock T. Squash: fast, fashionable and risky. The Times 1979 Nov 22.

- Canavan YM, O'Flaherty MJ, Archer DB, Elwood JH. A 10-year survey of eye injuries in Northern Ireland, 1967-76. Br $\mathcal{F}$ Ophthalmol 1980; 64:618-25.

${ }^{10}$ Hampshire County Council. Small area population forecast 1980 based. Winchester: HCC, 1980.

11 Office of Population Censuses and Surveys. The general household survey 1977. London: HMSO 1979.

12 Scrivener AB. Impact-resistant lenses. British fournal of Physiological Optics $1973 ; 28: 26-33$.

${ }^{13}$ Clemett RS, Fairhurst SM. Head injuries from squash: a prospective study. NZ Med F 1980;92:1-3.

(Accepted 9 fuly 1981)

\title{
Alcohol and Alcoholism
}

\section{The relation between consumption and damage}

\author{
RICHARD SMITH
}

The centrepiece of the alcohol debate for the last two decades has been how the amount of alcohol a society consumes is related to alcohol-associated damage in that society. The initial argument was whether the two were related at all, but now the issues are more how exactly they are related, how they are related in subgroups of the society, and what determines consumption.

\section{Achievements and failure of Sully Ledermann}

The idea that alcohol consumption and damage are related in a society has its origin in the work of Sully Ledermann. ${ }^{1}$ The mathematical details of his 30-year-old work, which was essentially theoretical, have been severely criticised, but from the ashes of his theory has risen a formidable phoenix. Ledermann made two assertions: firstly, that in a homogeneous population the distribution of alcohol consumption is a logarithmic normal curve (fig 1); and, secondly, that the number of people who drink a certain amount can be calculated if the average consumption is known. Few people interested in alcohol understand the mathematical details of Ledermann's theory just as few understand the criticisms made by Miller and Agnew, ${ }^{2}$ Duffy, ${ }^{3}$ and Skog. ${ }^{4}$ But they do understand the limitations of data gathered by surveys ${ }^{5}$ and that many graphs showing the distribution of consumption produced since Ledermann's time are not exactly log normal. ${ }^{6}$ People, particularly those who drink heavily, underreport how much they drink in surveys. Never-

British Medical Journal, London WC1H 9JR

RICHARD SMITH, BSC, MB, assistant editor

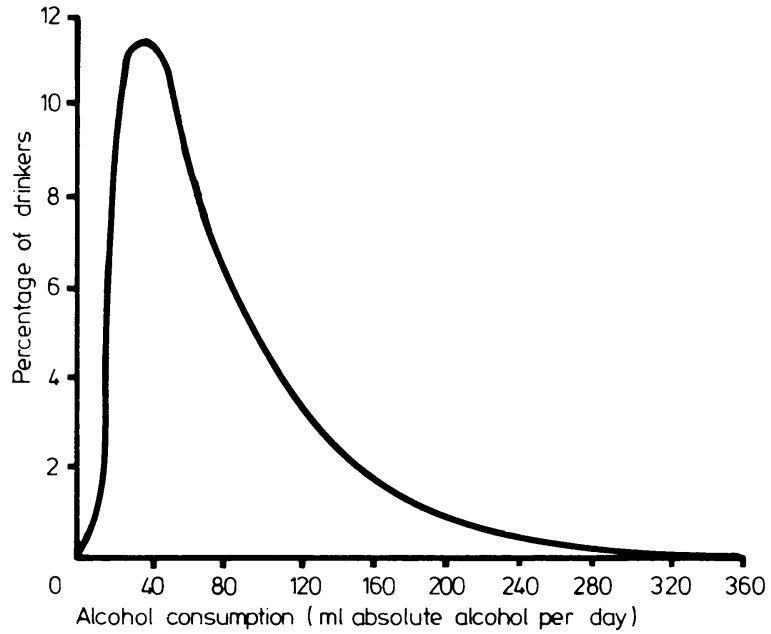

FIG 1-Hypothetical curve proposed by Ledermann that shows alcohol consumption in a homogenous population to be distributed in a logarithmic normal manner.

theless, the curves produced in various surveys, although not exactly log normal, are similar and are always skewed and unimodal.

\section{Empirical evidence}

The evidence that consumption and damage are related depends less on theory and more on empirical evidence. Because of tax and excise many countries-including Britain-have good records of national alcohol consumption (they do not record 